DOI https://doi.org/10.30525/978-9934-26-110-7-14

\title{
СПЕЦИФІКА НЕОМІФОЛОГІЧНОГО ХРОНОТОПУ В РОМАНІ ЮРІЯ ВИННИЧУКА «ТАНГО СМЕРТІ»
}

\author{
Медведчук О. П. \\ аспірантка кафедри історії украӥнської літератури, \\ теоріі літератури та літературної творчості \\ Інституту філології \\ Київський національний університет імені Тараса Шевченка \\ м. Київ, Украӥна
}

Роман «Танго смерті» має доволі ускладнену композиційну структуру. Дослідниця Романенко О. слушно зауважує, що «це текст, якому властиві ознаки метажанровости та метасюжетности. Танго смерти - метасюжетний твір, зі складною сюжетно-композиційною будовою, внутрішня структура цього тексту орієнтована на те, щоб «у межах одного твору охопити усі можливі жанрові елементи» [5, с. 150].

У творі наявні дві головні сюжетні лінії, які почергово змінюють одна одну, а наприкінці роману об'єднуються. Перша сюжетна лінія це історія чотирьох героїв, які живуть у Львові до Другої світової війни і у воєнний час; друга - життя історика літератури Мирка Яроша у 80-90-ті роки XX ст.

У таких переходах від однієї оповіді до другої (розділи про минуле автор позначає латинськими літерами, а про сучасне - цифрами) дослідники вбачають аналогію з самим танцем танго, якому притаманне чергування наближення й віддалення танцюристів. Крім цього, на думку дослідниці Олійник С., Ю. Винничук вдається до жанру криптоісторії, поєднуючи історичні події із фантастичними, наповнюючи реальність міфологічними смислами [4].

Отже, основний часопростір у романі являє єдиний топос Львова, який кардинально змінює війна, та два часові виміри - минулий $\mathrm{i}$ сучасний. Їх найчастіше і розглядають у своїх працях літературознавці. Але варто звернути увагу на існування ще двох просторово-часових вимірів - неоміфологічних: бібліотеку, в яку іде працювати Орест Барбарика після похоронного бюро, та територіальну частину Львова Знесіння, де відбуваються різні містичні речі.

Бібліотека являє собою окремий ірраціональний простір, у якому діють свої закони, в якому час має свої незвичайні властивості. Тут автор об’єднує в одну цілісність дві міфологеми - бібліотеки та лабіринту: 
«Книгозбірня виявилася таким собі лабіринтом височезних стелажів, між якими завиграшки можна було заблудитися» [1, с. 128]. Бібліотека виступає символом знання, пам'яті, сховку сакральних відомостей, а лабіринт вказує на те, що здобути найпотаємніші знання можна лише пройшовши випробування, подолавши певний шлях.

Свідченням того, що цей простір існує в окремому надприродному вимірі $є$ дивні речі, які там відбуваються: «З'являються якісь люди, потім зникають і з'являються знову. Абисте знали,... що тут уже не один заблукав у цих паперових нетрях, тож ви мусите пильнуватися і рухатися суворо за стрілками, ніколи не збиваючись 3 маршруту, інакше можете потрапити туди, звідки вже повернення нема» [1, с. 132]. Тут можна почути містичний шепіт, знайти свіжі морські водорості, побачити між стендами риб'ячий хвіст. Тобто, бібліотека є простором, який поєднує різні світи - реальний та надприродний.

Увиразнюється це незвичайне місце образом бібліотекарки Конопельки, якій більше 100 років, яка має феноменальні пам'ять і зір, нереальні знання й логіку. Фантастичність цього образу підсилюється здатністю жінки літати у повітрі за допомогою протягу. Тобто, можемо зробити висновок, що Ю. Винничук витворює міфічний образ хранителя пам'яті та знання, який наділений надзвичайними властивостями.

Містичною видається і постать самого директора бібліотеки, який, за словами Конопельки, вже давно помер і є тільки духом: «Одного разу перетяг звіяв картку паперу з мого столу, шпурнув їі на пана директора, i та картка пролетіла крізь нього...» [1, с. 132]. Тому знаковим у цьому контексті $є$ використання автором метафоричного порівняння бібліотеки iз потойбіччям: «Бібліотека - це потойбіччя, Аїд, і ви як Юний Орфей, спустилися у це провалля»[1, с. 133]. Про те, що час тут також спливає інакше, аніж у реальному світі, свідчить вигляд штату книгозбірні: «люди різного віку і різної статі, яких, проте, єднало одне: вбрані вони були так, ніби випірнули 3 минулого сторіччя за бабці Австрії...» $[1$, c. 133]. Отже, час тут рухається сповільнено, ще більше відокремлюючи бібліотеку від реального світу.

Ю. Винничук вдається в романі до різних містифікацій, вигадок, інтертексту та алюзій. Дослідниця Левченко Г. зауважує: «Такий гротесково очуднений образ бібліотеки нагадує образи скрипторію та бібліотеки у романі У. Еко «Ім'я рози» [2]. Пошук частини загубленого трактату Калькбреннера також має схожі риси із детективною лінією роману У. Еко. Проте Ю. Винничук насичує свою оповідь притаманними його стилю нісенітницями, гротеском та гумором, алогічністю у міркуванні, яке доходить до абсурду. 
Мандрівка Ореста у таємні, закриті фонди бібліотеки описана у дусі авантюрно-пригодницьких романів та має багато спільного із міфологічним шляхом античних героїв, який має випробувати мандрівника на хоробрість та кмітливість. Простежується і зв'язок такої подорожі 3 ініціацією героя, що теж походить із міфів: «Не один пішов і не вернувся... Але не ви. Я вірю в вас. Ви повернетесь із перемогою... Над самим собою. Над своїми страхами»[1, 155]. Як і в романі «Мальва Ланда» письменник зміщує акценти та видозмінює давній сюжет, адже лабіринт бібліотеки, хоч і повний дивовижних речей, проте ховає таємні знання, а не $\epsilon$ осередком зла.

Міфічний простір таємних фондів бібліотеки ще більш містичний та наповнений надзвичайними явищами, як-от: потяг-привид, який везе пасажирів, одягнених за австрійською модою, а на одній із зупинок вони щось розпачливо кричать, а згодом заспокоюються і їдуть далі; чи сніжинки, які падають у вигляді літер та розділових знаків, запах моря i водоростей, шум хвиль і невідомі морські істоти, які виходять з-під підлоги. Часом бібліотека описана як жива істота, яка має свою шурхотливу мову і захищає свої володіння. Дослідниця Махник М. зазначає, що «просторове наповнення Винничукової бібліотеки набуває метафоричного значення, тобто сприймається як особливий складний світ, як нерозгадана загадка, містифікація» [3].

Письменник вдається до десакралізації простору, в якому захований трактат із нотами Калькбреннера, оскільки додає до описів гумористичні елементи, які абсолютно не співвідносяться ні з сакральністю, ні 3 бібліотекою загалом. Наприклад, запах шинки, ковбаси, шпондерки, що дозрівали не в диму, а в тумані, що височів попід високими стелями бібліотеки: «У ніздрі мені вдарив запах не тільки старих фоліантів, цвілі й шкіри, дерев'яних стелажів, поточених шашелем, а й якийсь дивний i незбагненний, як для цього місця, фантазійний запах вудженого м'яса.» [1, с. 163]. Або наявність вина чи постільної білизни у визначених місцях, щоб відвідувачі мали змогу відпочити після блукання лабіринтами стелажів.

Неоміфологічний часопростір бібліотеки Оссоленіуму - це непередбачуваний, містичний та гростесково-фантастичний простір, моделюючи який, автор опирається на міфологічні традиції та застосовує прийоми інтертекстуальності.

Інший містичний хронотоп - Знесіння, згадується в обох сюжетних лініях роману. Це незвичайне місце у Львові, в якому не визначається час, де людина може побачити своє минуле або майбутнє, в якому фантастичне стало звичайним явище. 
Вже сама назва $є$ дуже символічною в контексті загальної семантики твору. «Знесіння» - тобто воскресіння. Справді, тут пам'ять здатна воскресити події та людей, про які герої вже давно забули.

Про містичність Знесіння Ярошеві розповідає сусідка Стефця. Професор, зацікавившись, теж вирушає у це загадкове місце. Ю. Винничук наголошує на незвичайних властивостях часу, оскільки герой з'являється на Знесінні ополудні, який в українській ритуально-міфологічній культурі асоціюється із завмиранням життя. Яскраве світло сонця, полуденна тиша та містичний спокій - все це увиразнює таємничу атмосферу Знесіння. Тут Ярош побачив дідуся із онуком, які виглядали так, наче зійшли із старих світлин, «йому навіть здалося, що він перемістився у часі» [1, с. 64]. До того ж герой відчуває, що він їх добре знає, але не може пригадати. Жіночий голос, який покликав дідуся із хлопчиком, також був знайомий і «ніби пробивався крізь хащі снів». Все побачене викликає у Яроша ностальгію за своїм дитинством, тугу за батьками.

Фантастичність простору Знесіння згадується і в сюжетній лінії, яка співвідноситься із минулим. Розповідаючи Оресту про потяг-привид, Міля згадує, що вона його бачила саме на Знесінні: «Якась нестримна сила потягнула мене туди... я вже взялася рукою за поруччя і підняла ного, коли раптом помітила у вікні знайоме обличчя - то була моя бабуся... Ї̈і обличчя було спотворене жахом, вона щось кричала до мене...» $[1,164]$.

Тобто, у часопростір Знесіння відбуваються незвичайні події, тут можливі подорожі в часі власної пам'яті, це місце, де реальність перетинається із фантастичністю та стирається межа між світами.

Отже, завдяки вдало інтегрованому у реальний та історичний хронотоп роману неоміфологічного часопростору автор формує самобутній культурно-історичний простір міста Львів, витворюючи навколо нього ауру містичності, міфічності та надприродності.

\section{Література:}

1. Винничук Ю. Танго смерті : роман. Харків : Фоліо, 2018. - 364 с.

2. Левченко Г. Трюк, атракціон i гротеск у поетиці роману Юрія Винничука «Танго смерті». URL: https:// journals.indexcopernicus.com/api/file/viewByFileId/225594.pdf

3. Махник М. Моделювання мотивів та образів часопростору у романі «Танго смерті» Юрія Винничука. URL: http://www.kspu.edu/ FileDownload.ashx/Матеріали\%20конференціі\% 20(травень).pdf?id=fab367 00-b534-407c-929a-13e25c98bc42 
4. Олійник С. Побутування фантастичного у сучасній українській прозі. Синопсис: текст, контекст, медіа. 2013. № 3-4. URL: http://nbuv.gov.ua/UJRN/stkm_2013_3-4_8

5. Романенко О. «Танго смерті» Ю. Винничука: масова чи висока література? Spheres of Culture. Volume V - VI. Lublin, 2013. C. 150-160.

DOI https://doi.org/10.30525/978-9934-26-110-7-15

\title{
ТИПИ ІНТОНАЦІЙ ПЕРСОНАЖІВ В ІСТОРИЧНИХ РОМАНАХ П. КРАЛЮКА («ШЕСТИДНЕВ, АБО КОРОНА РОДУ ОСТРОЗЬКОГО», «СИЛЬНІ ТА ОДИНОКІ»)
}

\author{
Мізінкіна О. О. \\ кандидат філологічних наук, \\ доиент кафедри загального та слов 'янського літературознавства \\ Одеський національний університет імені I. І. Мечникова \\ Чмир А. В. \\ учитель украӥнської мови та літератури \\ Одеська загальноосвітня школа № 56 I-III ступенів \\ Одеської міської ради Одеської області \\ м. Одеса, Україна
}

Питанням інтонації в основному займались лінгвісти (Віра Білошапкова, Олена Бризгунова та ін. «Сучасна російська мова»; Гульфія Давлєткулова «Поняття інтонації у лінгвістичній і методичній літературах»; Наталія Калиниченко «Інтонація як засіб виразності в озвучуваному художньому тексті»; Гінтаутас Кундротас, Алексас Бружас «Інтонація в художньому тексті: література постмодерна (Ю. Іванаускайте «Фортеця сплячих метеликів», В. Сорокін «Бенкет»)»; Емма Нушикян «Типологія інтонації емоційного мовлення»; Людмила Путіліна «Авторські засоби вираження інтонації у французькому художньому тексті»; Наталія Свєтозарова «Інтонація в художньому тексті»). 3-поміж літературознавців значення інтонації персонажів у художньому творі вивчали Людмила Польшикова («Інтонація як проблема поетики»), Андрій Єсін («Принципи і прийоми аналізу літературного твору») та ін. На важливості інтонації як засобу, який здатен впливати на розуміння адресата, наголошує Надія Гаврилюк: 